\title{
A methodology for truck allocation problems considering dynamic circumstances in open pit mines, case study of the Sungun copper mine
}

The Mining-Geology-Petroleum Engineering Bulletin UDC: $622.6 ; 519.85$

DOI: $10.17794 /$ rgn.2019.4.6

Preliminary communication

\author{
Amin Moniri-Morad'; Mohammad Pourgol-Mohammad ${ }^{2}$; Hamid Aghababaei ${ }^{1}$; Javad Sattarvand ${ }^{3}$ \\ ${ }^{1}$ Department of Mining Engineering, Sahand University of Technology, 51335-1996, Tabriz, Iran \\ ${ }^{2}$ Department of Mechanical Engineering, Sahand University of Technology, 51335-1996, Tabriz, Iran \\ ${ }^{3}$ Department of Mining and Metallurgical Engineering, University of Nevada, 89557, Reno, USA
}

\begin{abstract}
Truck allocation problems are considered as one of the most substantial factors in the achievement of planned production capacity in the mining industry. Traditional truck allocation techniques (e.g. mathematical programming, queueing theories) have undergone different levels of simplifications in formulating actual haulage operations under heterogeneous circumstances. In this study, the truck allocation problem is analysed through the development of the simulationbased optimization (SBO) method for the optimization of truck assignment considering uncertainties during fleet operation. This method provides an integrated structure by the simultaneous combination of optimization and stochastic discrete-event simulation. The objective function is to minimize the total number of trucks for haulage operation with discrete-event simulation employed to model the constraints. As a case study, the fleet operation of the Sungun copper mine is investigated to accomplish an optimal truck allocation for various working benches in the mine site. Operation details are evaluated through different indicators such as utilization, waiting times, and the amount of transported materials for each working bench. Finally, the operation bottlenecks are recognized for each situation.
\end{abstract}

\section{Keywords}

Haul truck allocation, Optimization, Discrete-event simulation, Production capacity

\section{Introduction}

A shovel-truck system is considered as one of the most prevalent raw material transportation systems in open-pit mines. This kind of system has several advantages compared to other methods such as mobility, climbing ability and short cycle times. However, loading and hauling equipment are considered as costly assets, leading to vital capital and operating costs. Nowadays, mining companies have employed diverse approaches to mitigate their costs and improve fleet capacity such as increasing capacities of the shovels and trucks, optimization of fleet size, efficient truck dispatching policies, as well as enhancement of fleet performance and reliability.

Truck allocation plays a significant role in fleet efficiency and productivity in the mining industry. As a matter of fact, an imprecise determination of the required number of trucks leads to major challenges during a haulage operation including shovel idle times (undertrucked estimations), truck waiting times and queues at shovels (over-trucked estimations).

There are various studies for modelling and the optimization of truck allocation problems. In the studies,

Corresponding author: Mohammad Pourgol-Mohammad mpourgol@gmail.com different objectives have been considered for truck allocation problems, encompassing the minimization of the number of trucks or the maximization of raw material production. Most of the approaches were associated with steady-state estimation procedures without considering effective factors like haul road circumstance, stochastic cycle times, truck waiting times, truck breakdowns, real-time dispatching policies, as well as the shovel-truck match factor (Krzyzanowska, 2007; Burt and Caccetta, 2014; Chaowasakoo et al., 2017). These kinds of analyses ignore to investigate the actual haulage fleet operation, which leads to vague and imprecise estimation procedures (Moniri-Morad et al., 2019). The common steady-state allocation methods can be categorized into analytical techniques, mathematical programming and queueing theory.

An analytical technique was proposed by Zhang to compute the optimal fleet size to fulfil the transportation goals (Zhang and Xia, 2015). Mathematical programming has been developed by several authors such as Burt et al. (2005), Fioroni et al. (2008), Subtil et al. (2011), Ta et al. (2013) and Dabbagh and Bagherpour (2019), which have developed linear programming models. Souza et al. (2010) and Gurgur et al. (2011) evolved mixed integer programming models for the allocation problem. In general, the analytical techniques and math- 
ematical programming are associated with different levels of mathematical simplifications in modelling nonlinearities and formulation of the actual haulage operation, leading to an unrealistic estimation process.

Queueing theory was considered for the allocation problem by various authors such as Alkass et al. (2003), Krause and Musingwini (2007) and Ercelebi and Bascetin (2009). Queueing theory is implemented in order to consider some operational uncertainties such as queue lengths, waiting and idle times of trucks and shovels. Nevertheless, complex and large-scale problems make it difficult to formulate the real haulage operation.

Discrete-event simulation (DES) has been utilized in various studies to model and formulate actual haulage operation and uncertainties. Various researchers have worked in this field consisting of Castillo and Cochran (1987), Bonates and Lizotte (1988), Ataeepour and Baafi (1999), Basu and Baafi (1999), Hashemi and Sattarvand (2015), Chaowasakoo et al. (2017).

The DES overcomes the limitations and deficiencies of the previous techniques such as analytical methods, mathematical programming, and queueing theories. In other words, it formulates the actual haulage operation with a lower level of simplification, a high level of operational constraints and stochastic phenomena. However, it is necessary to optimize the simulation model to reach the desirable goals.

This study is aimed to develop a simulation-based optimization method for the allocation of trucks to a loading system. In this approach, the optimal truck allocation is derived by modelling and formulation of stochastic procedures during a haulage operation comprising waiting times of trucks, shovel idle times, stochastic times for truck load, haul, dump and return processes. The optimization program is involved in two key parts including mixed integer programming as an objective function and developing DES for modelling haulage operation constraints. The proposed simulation-based optimization method works based on making a systematic linkage between the objective function and DES model in such a way that the DES is consecutively connected to the objective function and evaluates it until the optimum solutions are found.

\section{Methods}

Simulation optimization approaches are considered as an alternative where there are complex operations and stochastic processes. In this study, a simulation-based optimization method is developed to make the best truck assignments for each working bench in open pit mines. Figure 1 demonstrates the step-by-step research methodology for a simulation-based optimization model. To configure the model, an objective function is developed for the allocation problem, then a DES model is considered to formulate the operation constraints. The proposed methodology is comprised of an objective func-

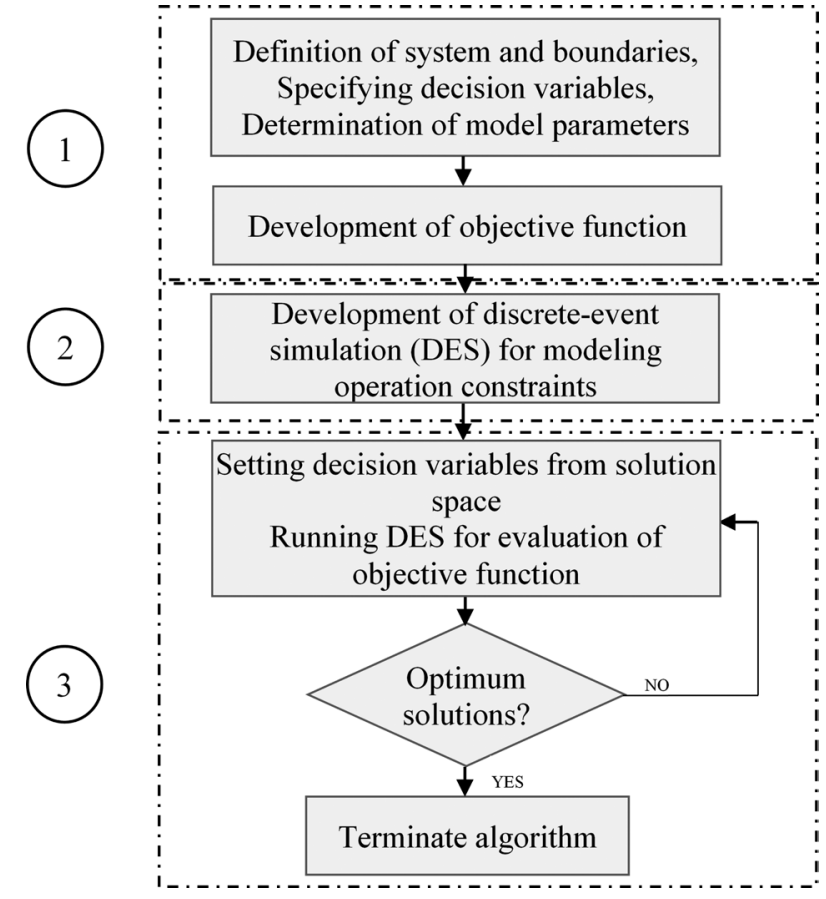

Figure 1: Step by step research methodology flowchart

tion, production constraints and operation constraints, which are characterized by the development of the DES model for an actual haulage operation.

\subsection{Objective function}

According to Figure 1, step 1 coincides with the definition of a system, specifying decision variables, model parameters, as well as mathematical formulation of the objective function for the optimization program. The mathematical expression (1) is represented for the objective function as follows:

$$
\operatorname{Min} \sum_{a \in A} \sum_{w \in W} y_{a w}+\beta \sum_{a \in A} \sum_{w \in W} R_{a w}
$$

where:

$y_{a w}-$ the number of allocated truck type $(w)$ to shovel (a);

$\beta-$ penalty value, which is devoted to the objective function;

$R_{a w}$ - the amount of transported material from shovel (a) by truck type (w).

The objective function is characterized to capture a minimum number of allocations of truck type $(w)$ to shovel $(a)$. In the objective function, a positive penalty value is devoted to $\beta$ when the extracted material $\left(R_{a w}\right)$ is less than the planned production capacity $(P)$. Otherwise, the $\beta$ value is set to zero. In this way, the minimum expected value is obtained for the objective function.

\subsection{Model constraints}

Step 2 deals with the modeling and formulation of optimization constraints. There are two types of constraints 
(2) and (3) comprising production and operation constraints.

\section{Production constraints}

$$
\begin{gathered}
\sum_{a \in A} \sum_{w \in W} R_{a w} \geq P \\
y_{a w} \geq 0 ; R_{a w} \geq 0 \quad \forall a \epsilon A, \forall w \in W
\end{gathered}
$$

where:

$P$ - the planned production capacity;

$R_{a w}$ - the amount of transported material from shovel (a) by truck type (w).

The constraint (2) is considered as a production constraint, which ensures that the amount of the extracted material is more than the minimum amount of the production plan. As mentioned before, the value of parameter $(\beta)$ depends on the the constraint (2). As a matter of fact, it is set to zero when $R_{a w}>P$. Otherwise, a positive penalty value is devoted to the objective function. Expression (3) enforces the integrality and non-negativity of integer and continuous decision variables, respectively.

\section{Operation constraints}

In general, the complexity of a mining operation leads to the utilization of tools with higher flexibility for recognizing and optimization of the operational bottlenecks. Simulation techniques are widely considered to imitate the natural paradigms and infrastructures of certain frameworks. In this regard, a haulage operation is carried out under stochastic and uncertain conditions. To simulate such a stochastic environment, there are two types of simulation techniques including static and dynamic simulation. The static simulation model describes a system state at a specific point of time. In other words, there is no demand for making an explicit model of changes during a span of time. Monte Carlo simulation is considered as a kind of static simulation model. A dynamic simulation characterizes a system during an interval of time. Furthermore, a dynamic simulation model can be classified as a discrete or continuous model. In the continuous model, the state of the system continuously changes over time, whereas, a discrete simulation model is applied where the system state changes only at discrete points of time (Leemis and Park, 2006). Discrete-event simulation (DES) is taken into account as a kind of dynamic simulation model. In this model, the state of the system immediately changes in response to explicit discrete events such as arrivals, departures, change of shifts, failure and inaccessibility of resources and entities. A discrete event simulation model is developed to formulate haulage operation constraints and restrictions for the optimization of a program. This method is based on the generation of some entities, passing through a network of servers (service stations) to do its mission. In the process, if a server is busy, the entities

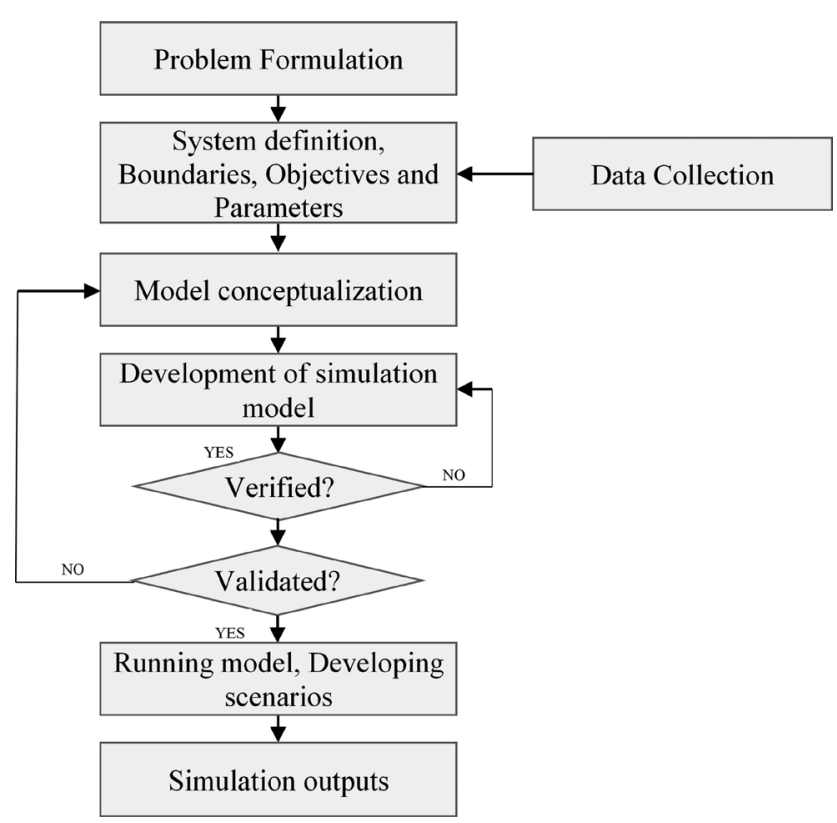

Figure 2: Simulation model structure flowchart

(Banks et al., 2005)

wait to begin their activity. In addition, there are several logic gates to send the entities to their proper destination (e.g. waste dump or ore crusher). One of the key aspects of the DES refers to specifying work duration for each activity such as loader service times, truck traveling times and material unloading times. To deal with this, historical time data is collected regarding haulage cycle times consisting of load, haul, dump and return processes. Then, a proper probabilistic distribution function is fitted into the time data.

A typical simulation model has a structure, which can be described by Figure 2 (Banks et al., 2005). In Figure 2, the first step is associated with formulating and stating a problem. The second step is involved in the system configuration, its boundaries, objective functions, decision variables and model parameters. In this step, a field data collection process is considered to provide the required input parameters for a simulation model. Conceptualization of a model refers to making simplifications about unknown and complex paradigms in a real system. In the next step, a simulation model is developed based on the computer format by using programming languages. Verification is performed to confirm if the simulation model (e.g. logical structures) is run correctly. Otherwise, a debugging process is necessary for the simulation program. For example, if there is a mission for a logic gate to send a truck to a certain destination, it'll be opened up after the truck's arrival. Otherwise, there is a mistake in the program and it is necessary to write an accurate code for opening after the truck's arrival. Validation is considered to guarantee if the established simulation model fulfills the requirements of the actual system and its functionalities. Otherwise, it would be essential to accurately model an actual operation to mitigate the deviations between a simulation model and 
the actual system. Running models and developing scenarios are performed to investigate the effect of various scenarios and parameters on the simulation model. As a matter of fact, a simulation model is established to recognize the system bottlenecks and weaknesses by considering and evaluating different scenarios. The final step is concerned with a description of the analyses results for the model.

In a haulage operation simulation, there are two main logic gates consisting of truck arrival and departure incidents. These kinds of logic gates are utilized for different situations such as truck loading and delivery processes. According to Figure 3, if a truck arrival event occurs, then two states are made for the haulage system. In the first case, the shovel is idle and ready for servicing the truck. In the second case, the shovel is busy and the truck goes to queue line ( $n=$ Queue Length). After completing the service and departure of a truck, the shovel starts a new servicing process if there is at least one truck in the queue line. Otherwise, the shovel becomes idle until another truck arrives at the shovel. In general, the inter-arrivals of trucks and service times of shovels are often characterized by the generation of random numbers from probabilistic distribution functions. Average values are formulated for service times and inter-arrival times according to Equations (4) and (5).

$$
\begin{gathered}
\bar{\mu}=\frac{\sum_{i=1}^{m} \mu_{i}}{m} \\
\bar{\lambda}=\frac{\sum_{i=1}^{m} \lambda_{i}}{m}
\end{gathered}
$$

where:

$\bar{\mu}$ - average service time;

$\bar{\lambda}$ - inter-arrival time;

$\mu_{i}$ - service time for each event;

$\lambda_{i}$ - time between arrivals for each event;

$m$ - the total number of events.

The probability that a server may be idle $(P(e))$ is introduced according to Equation (6):

$$
P(e)=\frac{\sum_{j=1}^{p} e_{j}}{T}
$$

where:

$e_{j}$ - time interval during which a server is being empty;

$p$ - the whole number of servers that are idle;

$T$ - the total simulation time.

\subsection{Solution process}

The final step of Figure 1 is involved in the attainment of optimum solutions. In this step, decision variables are initially set to the model and then the DES mod$\mathrm{el}$ is run. The DES is connected to an objective function and the expected value is evaluated for the objective

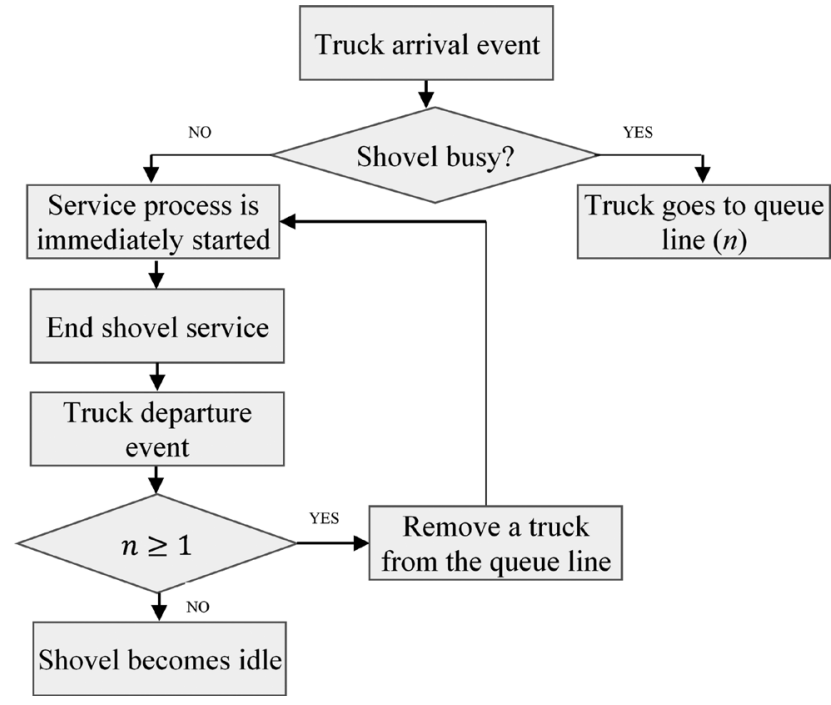

Figure 3: Occurrence of arrival and departure events flowchart

function. If the minimum number of trucks are allocated to the working benches, then the objective function requirements are satisfied and the optimum solutions are obtained for the allocation problem. Otherwise, another combination of decision variables are examined and the expected value of the objective function is computed. The process is repeated until the optimum combination of decision variables is reached. To complete the procedure automatically without recognizing and examining what-if scenarios, a Genetic Algorithm (GA) has been employed to attain the best solution. The genetic algorithm is taken into account as one of the common optimization methods for solving mixed integer programming models. In addition, it has the capability of obtaining global solutions for the optimization program. It is a search-based method, which does not capture local optimum solutions. The genetic algorithm contains several key phases, including coding value, population, selection, crossover, mutation and convergence criteria (Malhotra et al., 2011; Deep et al., 2009). The genetic algorithm is initially started by encoding a scheme to describe solutions over the search space. Then, a population of possible solutions are generated for the implementation of the optimization process. Thus, a fitness value is computed for each chromosome in the population. In the next step, a reproduction process is carried out using genetic operators comprising selection, crossover and mutation. To do this, the selection operator chooses a set of qualified chromosomes for the generation of new populations. Consequently, the crossover and mutation operators create the new chromosomes. The reproduction process is consecutively implemented until the convergence criteria is satisfied for the optimization program.

\section{Case study}

A case study is considered to establish an optimum allocation for trucks at the Sungun copper mine in Ta- 
briz, Iran. It is located in North-East Iran, in the East Azerbaijan Province. Figure 4 shows the location of the mine. The Sungun mine is considered as the second largest copper mine in Iran and it is estimated to have one billion tons of ore reserve in the mine. The mine haulage operation is accomplished through a loader-truck system. The mine contractor manages the haulage operation by using 25 to 30 trucks per shift. Different kinds of field data were collected for analysing the haulage fleet operation. Table 1 represents the gathered database for modeling the haulage operation system at the Sungun mine.

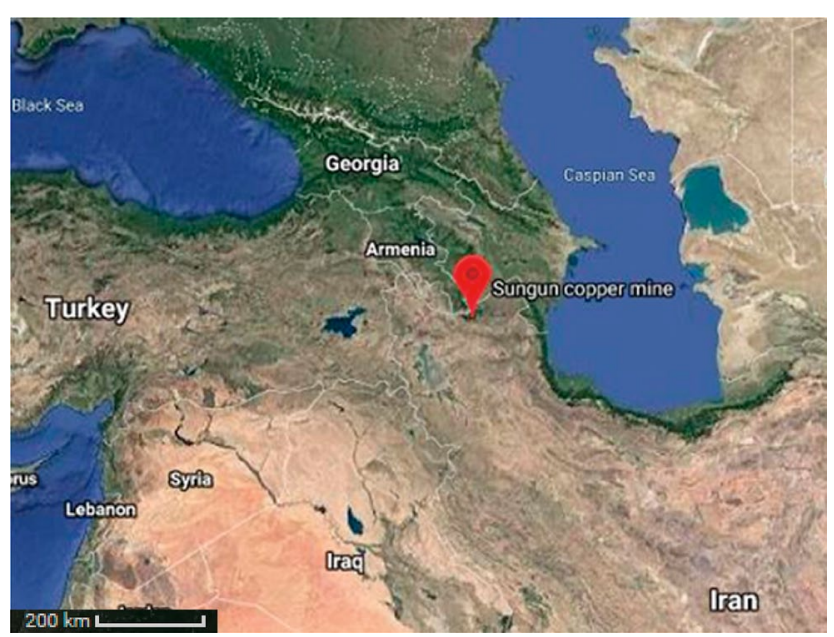

Figure 4: Sungun copper mine location in Iran (www.google.com/maps)
According to Table 1, there are three working benches of ore (working benches 1,2 and 3) and one working bench of waste (a fourth working bench). The extracted ore and waste materials are sent to the crusher and waste dump, respectively. The trucks of 60 tons are devoted to the third working bench and the trucks of 100 tons are assigned to working benches 1, 2 and 4. In addition, load, haul, dump and return times are reported with respect to each working bench in Table 1. Based on the mine production schedule, the production plan is given in the Table 1. Furthermore, the Sungun mine dispatching policy is associated with a fixed truck assignment. The collected data is implemented for modeling a haulage operation system in a discrete-event simulation model.

\subsection{Modelling operation by discrete-event simulation}

The haulage operation simulation was built in a MATLAB Simulink environment. A SimEvents toolbox is utilized for the development of a discrete-event simulation (MathWorks, 2015). In the SimeEvents, a haulage operation process is derived through a combination of various blocks and their elements such as entity generator, queue, servers, attribute assignments, random event generators, route paths, logic gates and Function blocks. Figure 5 displays the general structure for a haulage fleet operation at the Sungun copper mine.

According to the simulation model in Figure 5, all of the materials, loading system and trucks are initially

Table 1: Database for haulage fleet operation

\begin{tabular}{|c|c|c|c|}
\hline Operation Features & \multicolumn{3}{|c|}{ Numerical Values } \\
\hline Number of working benches & \multicolumn{3}{|c|}{4} \\
\hline Type of working benches & \multicolumn{3}{|c|}{3 working benches of ore, 1 working bench of waste } \\
\hline Number of unloading points & \multicolumn{3}{|c|}{2} \\
\hline Type of unloading points & \multicolumn{3}{|c|}{1 ore crusher, 1 waste dump } \\
\hline \multirow{4}{*}{ Capacity of loading systems } & \multicolumn{3}{|c|}{ Working bench 1: Hyundai excavator: $5.1 \mathrm{~m}^{3}$} \\
\hline & \multicolumn{3}{|c|}{ Working bench 2: Komatsu loader: $6.1 \mathrm{~m}^{3}$} \\
\hline & \multicolumn{3}{|c|}{ Working bench 3: CAT loader: $5.4 \mathrm{~m}^{3}$} \\
\hline & \multicolumn{3}{|c|}{ Working bench 4: Liebherr shovel: $18 \mathrm{~m}^{3}$} \\
\hline \multirow{4}{*}{$\begin{array}{l}\text { Average truck loading times (Seconds), } \\
\text { Average truck unloading times } \\
\text { (Seconds) }\end{array}$} & Working bench 1 to Crusher & Loading time: 255.6 & Unloading time: 50 \\
\hline & Working bench 2 to Crusher & Loading time: 306.6 & Unloading time: 43 \\
\hline & Working bench 3 to Crusher & Loading time: 226.8 & Unloading time: 34 \\
\hline & Working bench 4 to Waste Dump & Loading time: 117.6 & Unloading time: 45 \\
\hline \multirow{4}{*}{$\begin{array}{l}\text { Average truck haul and return times } \\
\text { (Seconds) }\end{array}$} & Working bench 1 to Crusher & Haul time: 792 & Return time: 612 \\
\hline & Working bench 2 to Crusher & Haul time: 402 & Return time: 313.8 \\
\hline & Working bench 3 to Crusher & Haul time: 486 & Return time: 426 \\
\hline & Working bench 4 to Waste Dump & Haul time: 510 & Return time: 384 \\
\hline \multirow{4}{*}{$\begin{array}{l}\text { Production plans } \\
\text { (Tons per shift) }\end{array}$} & Working bench 1 & \multicolumn{2}{|c|}{3400} \\
\hline & Working bench 2 & \multicolumn{2}{|c|}{5000} \\
\hline & Working bench 3 & \multicolumn{2}{|c|}{3000} \\
\hline & Working bench 4 & \multicolumn{2}{|c|}{5600} \\
\hline Size of trucks (Tons) & \multicolumn{3}{|c|}{100 and 60} \\
\hline
\end{tabular}




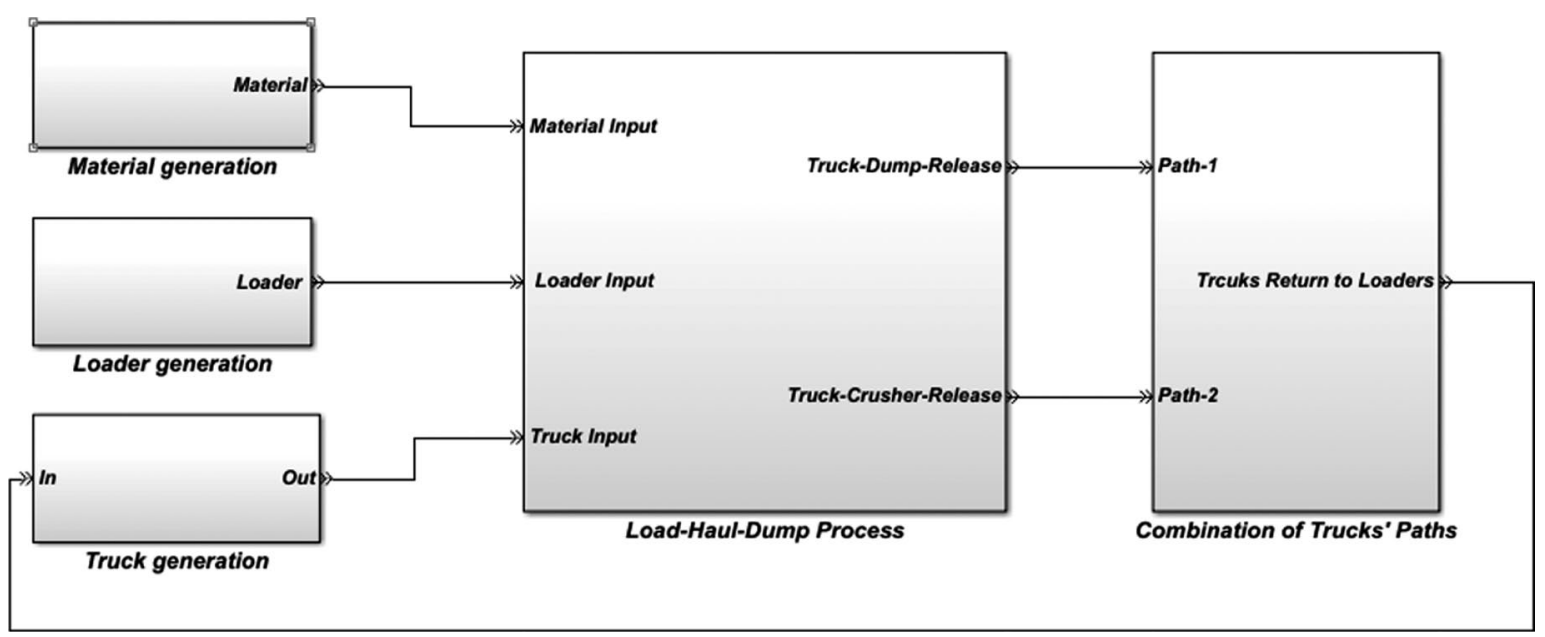

Figure 5: Haulage simulation structure

generated and assigned to working benches. Then, loadhaul-dump processes are implemented. Afterwards, the materials are sent to the proper destinations and the empty trucks return for their next allocation.

\subsection{Optimization results}

A genetic algorithm was completed to achieve an optimum truck allocation for the simulation-based optimization method. The required quantity of trucks was computed considering operational heterogeneities. A reallocation process may be required if the number of available trucks changes due to undesirable scenarios such as the occurrence of failures or breakdowns. There are various methods to investigate and analyse truck failures and breakdowns such as conditional monitoring of the trucks (Morad and Sattarvand, 2013), reliability-centred maintence (Morad et al., 2014), the Cox proportional hazard model (Ghodrati and Kumar, 2005; MoniriMorad et al., 2018) and the flexible parametric proportional hazards model (Moniri-Morad et al., 2018). As an alternative, reserve trucks would be considered to be substituted for the failed trucks to meet the production targets.

In this step, the established simulation model was validated based on an actual operation. According to one shift of operation, the number of 2, 4, 3 and 4 trucks were assigned to working benches of 1 to 4 , respectively. According to the simulation results, the amount of the transported materials were 2700, 7300, 3600, 8600 tons per shift from each working bench, respectively. These results were approximately accomodated to the actual operation. Therefore, the established model can be developed for similar situations.

In the next step, the established model was considered to find an optimum allocation of trucks for the working benches. In this case, the SBO method was developed for the model subject to meet the current production plans in a single shift. A particular production plan was devoted for each working bench so that it is essential to
Table 2: Optimization outputs for allocation of trucks to loading system

\begin{tabular}{|l|c|c|}
\hline Working benches & No. of departure & $\begin{array}{c}\text { Optimum truck } \\
\text { number }\end{array}$ \\
\hline 1 & 39 & 3 \\
\hline 2 & 60 & 3 \\
\hline 3 & 60 & 3 \\
\hline 4 & 64 & 3 \\
\hline
\end{tabular}

be met in a working shift. Table 2 gives the optimal quantity of trucks for working benches 1 to 4 in the simulation model.

As shown in Table 2, three trucks should be assigned to each working bench to maintain the minimum amount of the planned production capacity. In addition, the cumulative number of trucks assignments are computed for the working benches 1 to 4 as 39, 60, 60 and 64, respectively. The production plans and cumulative number of trucks assignments have been derived for one working shift. Figure 6 indicates the amount of transported materials and the production targets for the working benches. The amount of the transported materials are greater than the planned production capacity. Thus, the production constraints are satisfied by a minimum number of allocated trucks.

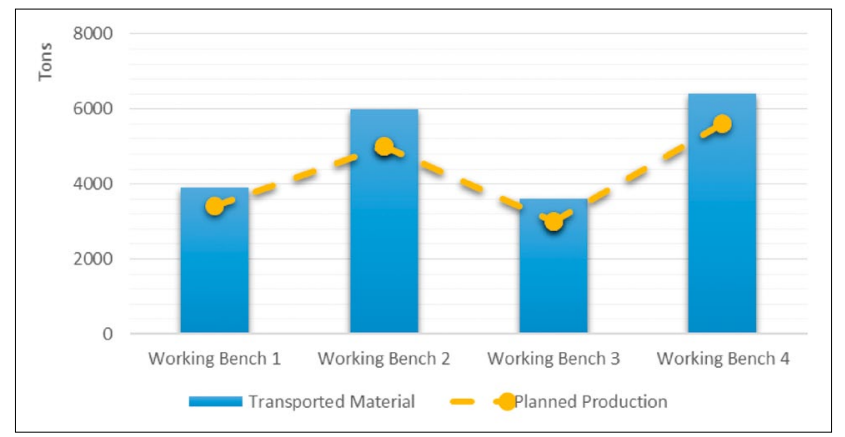

Figure 6: Results of the SBO method for different working benches 
Table 3: Analysing the built simulation model

\begin{tabular}{|c|c|c|c|c|c|c|c|c|c|}
\hline \multirow{2}{*}{ 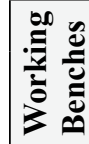 } & \multicolumn{3}{|c|}{ Utilization of Loading System } & \multicolumn{3}{|c|}{ Average Idle Times of Loading System } & \multicolumn{3}{|c|}{ Average Truck Waiting Times } \\
\hline & $\begin{array}{l}\text { Mean } \\
\text { (\%) }\end{array}$ & Distribution & Parameters & & Distribution & Parameters & & Distribution & Parameters \\
\hline 1 & 49.2 & Log-logistic & $\begin{array}{l}\alpha=3 \\
\beta=0\end{array}$ & $\begin{array}{l}0.0895 \\
(5.37 \mathrm{~min})\end{array}$ & Log-logistic & & & Log-normal & \\
\hline 2 & 79.9 & Weibull & $\begin{array}{l}\alpha=53.79 \\
\beta=0.807\end{array}$ & $\begin{array}{l}0.021 \\
(1.26 \mathrm{~min})\end{array}$ & Log-logistic & $\begin{array}{l}\alpha=17.039 \\
\beta=0.021\end{array}$ & $\begin{array}{l}0.0277 \\
(1.66 \mathrm{~min})\end{array}$ & Log-logistic & \\
\hline$?$ & 44.3 & Normal & $\begin{aligned} \mu & =0.443 \\
\sigma & =0.05\end{aligned}$ & & Log-logistic & & $\begin{array}{l}0.007 \\
(0.42 \mathrm{~min})\end{array}$ & Log-logistic & \\
\hline & 32.6 & Log-logistic & $\begin{array}{l}\alpha=44.75 \\
\beta=0.33\end{array}$ & $\begin{array}{l}0.0659 \\
(4 \mathrm{~min})\end{array}$ & Log-logistic & $\begin{array}{l}\alpha=30.31 \\
\beta=0.066\end{array}$ & $\begin{array}{l}0.0049 \\
(0.29 \mathrm{~min})\end{array}$ & Log-logistic & $\begin{array}{l}\alpha=4.65 \\
\beta=0.0045\end{array}$ \\
\hline
\end{tabular}

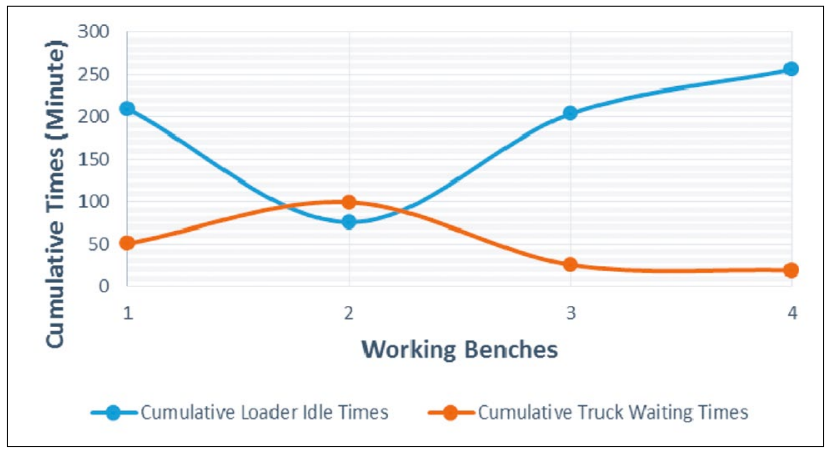

Figure 7: Average cumulative loader idle and truck waiting times

\section{Results and discussion}

The optimization results lead to find the optimum allocation of trucks to working benches with respect to existing operational and production constraints at the mine. However, it is necessary to analyse the simulation model to reveal the obstacles and bottlenecks for the mine haulage operation. Table 3 describes the simulation results for loader utilization, idle times and truck waiting times.

According to Table 3, the highest and lowest utilizations of the loading systems coincide with the second and fourth working benches (79.9 and 32.6 percent), respectively. The utilization of the loading system is taken into consideration as one of the most important bottlenecks, avoiding to organize the haulage operation efficiently. In Figure 7, average cumulative loader idle and truck waiting times are computed for each working bench during a shift roster.

According to Figure 7, the maximum and minimum loader idle times are related to the fourth and second working benches. In contrast, the maximum and minimum truck waiting times coincide with the second and fourth working benches. The analyses reveal that the ratio of loader idle times to truck waiting times are computed $4.13,0.76,8.1$ and 13.8 for working benches 1 to 4 , respectively. According to the results of SBO, it would be recommended to consider a real-time dispatching strategy for the haulage operation. Thus, the mine pro- duction schedules are reached with a smaller size of haulage fleet and the utilizations are improved for the loaders.

\section{Conclusions}

This study was focused on developing a methodology for the optimal allocation of trucks to a loading system. In this regard, a simulation-based optimization method was proposed based on the simultaneous combination of optimization and simulation techniques. In this approach, an acceptable level of operational complexities and uncertainties were considered for the optimization problem. This procedure leads to the creation of a realistic allocation of trucks with respect to a dynamic environment. To analyse the model, the Sungun Copper mine was considered as a real case study. In the case study, a minimum number of haul trucks were assigned to each working bench and somehow, the planned production capacity was fulfilled for the mine production system. Three trucks were allocated to each working bench as the optimal solution. The amount of transported materials was 3900, 6000, 3600 and 6400 tons from each working bench, respectively. In addition, methodology has the capability of analysing operation details including utilization, truck waiting times, and idle times of the loading systems. For example, the utilization of loading systems was $49.2,79.9,44.3$ and 32.6 , indicating the haulage system does not work efficiently. According to the operation indicators, the bottlenecks were recognized for the whole of the operation at the mine site. Finally, improvement of haulage fleet deficiencies such as a real-time dispatching policy are recommended to promote system efficiency and productivity.

\section{References}

\subsection{Published works}

Alkass, S., Khalil E. and Mohamed A. (2003): A computer model for selecting equipment for earthmoving operations using queuing theory. In: Amor, R. (eds): Proceedings of the CIB W78 20th International Conference on Construc- 
tion IT, Construction IT Bridging the Distance, CIB Report 284, Waiheke Island, New Zealand, 1-8.

Ataeepour, N. and Baafi, E.Y. (1999): ARENA simulation model for truck-shovel operation in despatching and nondespatching modes. International Journal of Surface Mining, Reclamation and Environment, 13, 125-129.

Banks, J., Carson, II., Nelson, B.L. and Nicol, D.M. (2005): Discrete-event system simulation. Pearson Prentice Hall.

Basu, A.J. and Baafi, E.Y. (1999): Discrete event simulation of mining systems: current practice in Australia. International Journal of Surface Mining, Reclamation and Environment, 13, 79-84.

Bonates, E. and Lizotte, Y. (1988): A computer simulation model to evaluate the effect of dispatching. International Journal of Surface Mining, Reclamation and Environment, 2, 99-104.

Burt, CN, and L Caccetta.(2014): Equipment selection for surface mining: a review. Interfaces, 44, 143-162.

Burt, C.N. and Caccetta, L. (2007): Match factor for heterogeneous truck and loader fleets. International Journal of Mining, Reclamation and Environment, 21, 262-270.

Castillo, D. and Cochran, J.K. (1987): A microcomputer approach for simulating truck haulage systems in open pit mining. Computers in Industry, 8, 37-47.

Chaowasakoo, P., Seppälä, H., Koivo, H. and Zhou, Q. (2017): Digitalization of mine operations: Scenarios to benefit in real-time truck dispatching. International Journal of Mining Science and Technology, 27, 229-236.

Dabbagh, A. and Bagherpour, R. (2019): Investigating the applicability of the imperialist competitive algorithm in the problem of allocating trucks to an open pit mine. The Mining, Geological and Petroleum Engineering Bulletin (Rudarsko-geološko-naftni zbornik), 34, 35-42.

Deep, K., Singh, K.P., Kansal, M.L. and Mohan, C. (2009): A real coded genetic algorithm for solving integer and mixed integer optimization problems. Applied Mathematics and Computation, 212, 505-518.

Ercelebi, S.G. and Bascetin, A. (2009): Optimization of shovel-truck system for surface mining. Journal of the Southern African Institute of Mining and Metallurgy, 109, 433-439.

Fioroni, M.M., Franzese, L.A.G., Bianchi, T.J., Ezawa, L. and Pinto, L.R. (2008): Concurrent simulation and optimization models for mining planning. In: Mason, S., Hill, R., Rose, O. and Moünch, L. (eds): Proceedings of the 40th Conference on Winter Simulation, Winter Simulation Conference, Miami, FL, USA.- IEEE, 759-767.

Gurgur, C.Z., Dagdelen, K. and Artittong, S. (2011): Optimisation of a real-time multi-period truck dispatching system in mining operations. International Journal of Applied Decision Sciences, 4, 57-79.

Ghodrati, B. and Kumar, U. (2005): Reliability and operating environment-based spare parts estimation approach: a case study in Kiruna Mine, Sweden. Journal of Quality in Maintenance Engineering, 11, 169-184.

Hashemi, A.S. and Sattarvand, J. (2015): Simulation based investigation of different fleet management paradigms in open pit mines-a case study of sungun copper mine (Symulacje I Badania Różnych Paradygmatów Wykorzystan- ia Floty Pojazdów I Urządzeń W Kopalniach Odkrywkowych. Studium Przypadku: Kopalnia Miedzi W Sungun). Archives of Mining Sciences, 60, 195-208.

Krause, A. and Musingwini, C. (2007): Modelling open pit shovel-truck systems using the Machine Repair Model. Journal of The South African Institute of Mining and Metallurgy, 107, 469-476.

Krzyzanowska, J. (2007): The impact of mixed fleet hauling on mining operations at Venetia mine. Journal of the Southern African Institute of Mining and Metallurgy, 107, 215-224.

Leemis, L.M. and Park, S.K. (2006): Discrete-event simulation: A first course. In: Fabrycky, W.J., Mize, J.H. (eds): Pearson Prentice Hall International Series in Industrial and Systems Engineering, 13 p.

Malhotra, R., Singh, N. and Singh, Y. (2011): Genetic algorithms: Concepts, design for optimization of process controllers. Computer and Information Science, 4, 39-54.

Moniri-Morad, A., Pourgol-Mohammad, M., Aghababaei, H. and Sattarvand, J. (2018): Reliability-based covariate analysis for complex systems in heterogeneous environment: Case study of mining equipment. Proceedings of the Institution of Mechanical Engineers, Part O: Journal of Risk and Reliability, 233,4, 593-604.

Moniri-Morad, A., Pourgol-Mohammad, M., Aghababaei, H. and Sattarvand, J. (2019): Capacity-based performance measurements for loading equipment in open pit mines. Journal of Central South University, 26, 6, 1672-1686.

Morad, A.M., Pourgol-Mohammad, M. and Sattarvand, J. (2014): Application of reliability-centered maintenance for productivity improvement of open pit mining equipment: Case study of Sungun Copper Mine. Journal of Central South University, 21, 2372-2382.

Morad, A.M. and Sattarvand, J. (2013): Condition monitoring of off-highway truck tires at sungun copper mine using neural networks (Monitorowanie stanu technicznego opon w ciężkich pojazdach terenowych eksploatowanych w kopalni miedzi sungun, przy użyciu sieci neuronowych). Archives of Mining Sciences, 58, 1133-1144.

Souza, M.J.F., Coelho, I.M., Ribas, S., Santos, H.G. and Merschmann, L.H.C. (2010): A hybrid heuristic algorithm for the open-pit-mining operational planning problem. European Journal of Operational Research, 207, 1041-1051.

Subtil, R. F., Silva, D. M. And Alves, J. C. (2011): A practical approach to truck dispatch for open pit mines. In 35th APCOM Symposium, Wollongong, NSW, Australia, 765-777.

Ta, C.H., Ingolfsson, A. and Doucette, J. (2013): A linear model for surface mining haul truck allocation incorporating shovel idle probabilities. European Journal of Operational Research, 231, 770-778.

Zhang, L. and Xia, X. (2015): An integer programming approach for truck-shovel dispatching problem in open-pit mines. Energy Procedia, 75, 1779-1784.

\subsection{Internet sources}

URL: www.mathworks.com/help/simevents/ (Accessed 2015). URL: www.google.com/maps (Accessed 18th August 2019). 


\subsection{Professional archives}

Moniri-Morad, A., Pourgol-Mohammad, M., Aghababaei, H. and Sattarvand, J. (2018): Reliability-based regression model for complex systems considering environmental uncertainties. In: Probabilistic Safety Assessment and Management (PSAM 14), Los Angeles, CA. psam14.org/proceedings/paper/paper_47_1.pdf.

\section{Acknowledgment}

We would like to thank operation management for their support at the Sungun Mine.

\section{SAŽETAK}

\section{Metodologija za dodjelu kamionskoga prijevoza u dinamičkim uvjetima otvorenoga kopa}

Problem raspodjele kamiona smatra se jednim od najvǎnijih čimbenika u postizanju planiranih proizvodnih kapaciteta u rudarstvu. Tradicionalne tehnike raspodjele kamiona (npr. matematičko programiranje, teorije čekanja u redu) podliježu različitim razinama pojednostavljenja u formuliranju stvarnoga prijevoza u heterogenim okolnostima. U ovome radu analiziran je problem raspodjele kamiona razvojem metode za optimizaciju raspodjele kamiona koja se temelji na simulaciji optimizacije (SBO) s obzirom na nesigurnosti tijekom rada kamionskoga voznog parka. Metoda osigurava integriranu strukturu simultanom kombinacijom optimizacije i simulacije stohastičkih diskretnih događaja. Ciljna je funkcija minimiziranje ukupnoga broja kamiona za transport sa simulacijom diskretnih događaja korištenih za modeliranje rubnih uvjeta. U ovome radu istražen je rad voznoga parka na primjeru rudnika bakra Sungun kako bi se postigla optimalna raspodjela kamiona pri različitim radnim operacijama na eksploatacijskome polju rudnika. Pojedinosti rada procijenjene su na temelju različitih pokazatelja kao što su iskorištenje, vrijeme čekanja i količina transportiranoga materijala za svaku radnu operaciju. Konačno, uska grla operacija prepoznata su za svaku situaciju.

\section{Ključne riječi:}

raspodjela kamiona, optimizacija, simulacija diskretnih događaja, proizvodni kapacitet

\section{Authors contribution}

Amin Moniri-Morad (PhD in mining engineering): participated in all phases of the research comprising modelling and formulation of simulation and optimization structures, running models and interpreting the results. Mohammad Pourgol-Mohammad (Associated Professor): participated in development of research methodology, verification and evaluation of the models and output. Hamid Aghababaei (Associated Professor): contributed in the case study and helped with field work and managed whole phases of research. Javad Sattarvand (Assistance Professor): helped with the initial idea, optimization process and regulated research methodology. 